\title{
PRESPEKTIF MEDIA DIANTARA ISU RADIKALISME DAN TERORISME (Sebuah Studi Pengerusakan Mushola di Minahasa Utara)
}

\author{
Arvin Hardian \\ Program Studi Penyiaran, arvin.ahr@bsi.ac.id
}

\begin{abstract}
Abstraksi
Dalam pembahasan "Media diantara Radikalisme Dan Terorisme" dengan tujuan untuk mengetahui seberapa besar pengaruhnya terhadap Islam ( studi kasus Minahasa Utara). Penulis melakukan analisis isi (content analysis) adalah penelitian yang bersifat pembahasan mendalam terhadap isi suatu informasi tertulis atau tercetak dalam media massa secara kualitatif dengan menggunakan teknik symbol coding, yaitu mencatat lambang atau pesan secara sistematis, kemudian diberi interpretasi. Dari hasil penelitian terhadap beberapa media nasional paska kejadian pengerusakan Mushola di Minahasa Utara minggu ke-5 Januari dan Minggu Ke-1 Februari 2020, diskripsi soal radiakalisme, terorisme, ektrimis dan intoleran nyaris tidak muncul dalam kontruksi pemberitaan. Media terlihat dengan sengaja menghilangkan elemen-elemen dari teknis jurnalistik, dengan bagaimana peristiwa dimaknai dan ditampilkan. Inilah sesungguhnya sebuah realitas politik. Media membangun, menyuguhkan, mempertahankan, dan mereproduksi, suatu peristiwa kepada pembacanya.
\end{abstract}

(Kata kunci: Media diantara Radikalisme Dan Terorisme)

\section{Abstraction}

In the discussion "Media between Radicalism and Terrorism" with the aim to find out how much influence on Islam (North Minahasa case study). The author conducts content analysis (content analysis) is a research that is in-depth discussion of the contents of a written or printed information in mass media qualitatively by using symbol coding techniques, namely recording symbols or messages systematically, then given an interpretation. From the results of research on several national media after the destruction of the mosque in North Minahasa the 5th week of January and the 1st Sunday of February 2020, the description of radiachealism, terrorism, extremism and intolerance almost did not appear in the construction of the news. The media are seen intentionally removing elements from technical journalism, with how events are interpreted and displayed. This is really a political reality. The media builds, presents, maintains, and reproduces an event to its readers.

(Keywords; the media between radicalism and terrorism)

\section{PENDAHULUAN}

Kehidupan masyarakat dunia yang serba modern saat ini, media sosial menjadi bagian sangat penting sebagai alat komunikasi antar individu baik dalam bentuk verbal maupun non-verbal, bahkan sudah menjadi turbelensi alam dinamika komunikasi. Namun, harus tetap diingat dan disadari bahwa media sosial tetap mempunyai dua ekses sekaligus: positif dan negatif, sama halnya dengan globalisme yang mempunyai dua dampak yang sama.

Dampak negatif dari media sosial dalam kajian komunikasi global adalah hilangnya budaya lokal (local wisdom) yang tadinya hanya turun temurun mampu sampai di 
seluruh penjuru dunia tanpa terkecuali Indonesia. Disini budaya bisa dibentuk dengan bantuan komunikasi yang didukung oleh teknologi.Dengan konsekwensi logisnya adalah budaya lokal terancam semakin menurun esensinya. Beberapa waktu lalu Indonesia digemparkan oleh, sekelompok orang yang

Massa juga merusak pagar bangunan mushola. Ironisnya tanggapan menteri Agama Fachrul Razi menanggapi kasus perusakan tempat ibadah di Minahasa Utara, Sulawesi Utara (Sulut), yang viral di media sosial. Fachrul menyatakan, perusakan tempat ibadah memiliki rasio yang sangat kecil dibanding dengan jumlah tempat ibadah di Indonesia

Dalam peristiwa diatas tidak ada satupun media yang mengaitkan dengan isu radikalisme, intoleran ataupun terorisme. Lantas bagaimana kondisi struktur sosial di Indonesia yang di stimualasi media dalam konflik yang

\section{KAJIAN LITERATUR}

\section{Media Sosial}

Karakter media sosial yang tanpa batas membuat penyebaran paham radikal semakin sulit dihalau. Komunikasi di media sosial membuat penyebaran paham radikal ini meningkat dan sulit dihalau. Media sosial itu bersifat borderless dan luas, partisipatif dengan peserta beragam, bersifat private dalam penggunaan, komunikasi bebas dan cepat dan pesan mudah dibuat.

Karakter media sosial itu berseiring dengan meningkatnya penggunaan media sosial semakin mempercepat penyebaran paham radikal di media sosial. Percepatan paham radikalisme menyebar juga disebabkan oleh akselerasi pengguna internet yang meningkat. Dominasi situssitus hoaks dan radikalisme juga masih tinggi. menghancurkan bangunan rumah ibadah . Sebuah mushola di Perum Agape, Desa Tumaluntung, Kabupaten Minahasa Utara (Minut), Sulawesi Utara (Sulut), Rabu (29/1/2020) malam dihancurkan sekolompok orang. Mereka menghancurkan bangunan mushola, baik di dalam gedung hingga ke bagian atap. dilatari oleh agama?. Sementara paham yang radikal, ekstrim, dan fundamental akan melahirkan acaman terhadap dirinya serta sekitarnya yang akan dirasakan dalam jangka waktu yang perlahan sehingga menjadi isu teror dimana-mana sbagaimana yang telah dan sedang terjadi saat ini.

Hal-hal tersebut melatarbelakangi dan memotivasi penulis untuk mengkaji dan meneliti hal tersebut sehingga penulis mengambil judul "Media diantara Radikalisme Dan Terorisme: dengan tujuan untuk mengetahui seberapa besar pengaruhnya terhadap struktur masyarakat Islam pada umumnya.

Mengutip definisi radikalisme dari Badan Nasional Penanggulangan Terorisme (BNPT) ciri-ciri radikalisme adalah paham yang menginginkan perubahan secara cepat dengan kekerasan, paham yang mendukung, menyebarkan dan mengajak menjadi anggota ISIS serta paham yang mendefinisikan jihad secara terbatas yang menjurus pada bentuk kekerasan untuk mewujudkannya.

Menurut Stanley J. Baran dan Dennis K. Davis (2012 : 55) asumsi dasar teori masyarakat massa terkait dengan individu, peran media, dan sifat perubahan sosial adalah sebagai berikut:

1. Media memiliki kekuatan memaksa dalam masyarakat yang dapat menumbangkan normanorma dan nilai-nilai hingga merusak tatanan sosial. Untuk mengatasi bentuk ancaman ini media harus berada di bawah kontrol elit;. 
2. Media secara langsung dapat mempengaruhi pikiran orang dan mengubah pandangan mereka tentang dunia sosial;

3. Ketika pikiran orang diubah oleh media maka seluruh konsekwensi buruk dilihat sebagai hasil yang tidak hanya membawa kehidupan individu pada kehancuran namun juga menciptakan berbagai permasalahan sosial dalam skala besar;

4. Rata-rata orang sangat rapuh atau tidak berdaya menghadapi media karena dalam masyarakat massa mereka diisolasi dari institusi sosial tradisional yang sebelumnya melindungi mereka dari manipulasi media;

5. Kekacauan sosial yang diinisiasi oleh media kemungkinan akan di atasi dengan pembentukan tatanan sosial totaliter;

6. Media massa mau tidak mau memperdebatkan bentuk budaya yang lebih tinggi, yang menyebabkan penurunan peradaban secara umum.

Dalam konteks Indonesia saat ini, media massa dengan berbagai varian dan platformnya menjadi bagian penting kehidupan masyarakat. Hanya saja, perkembangan media massa (terlebih media sosial) ini oleh masyarakat Indonesia diterima apa adanya tanpa nalar kritis mempelajari ideologi-politik yang bermain di belakangnya, dengan begitu masyarakat Indonesia hanya menjadi pengguna pasif, konsumen berita yang menelan bulat informasi tanpa ada budaya "saring sebelum sharing"

Pandangan teoritis dari Joshua Meyrowitz (1985) dan Robert McChesney (2004) benar, kita kini sedang kehilangan sentuhan dengan budaya-budaya berbasis lokal dan sedang bergerak ke dalam lingkungan budaya global yang sepenuhnya berbasis media sosial . Disisi lain teori budaya Danesi, (2009 : 189), adalah suatu masyarakat terdiri dari sejumlah besar orang yang sangat mudah dipengaruhi oleh media massa dan birokrasi pemerintah. Bahkan content media cenderung melayani kepentingan pemegang kekuasaan politik dan ekonomi. Media juga memiliki kecenderungan untuk membantu publik bebas dalam menerima keberadaannya sebagaimana adanya.

Menurut pendekatan instrumental Marxis, media merupakan bagian ideal dari berbagai kelas sosial yang saling bersinggungan. Pendekatan ini yang membuat beberapa klaim yaitu para pemilik media massa memiliki kendali langsung terhadap berbagai ide yang dikomunikasikan melalui media massa. Sementara pendekatan Marxis memandang bahwa khalayak media massa merupakan khalayak yang pasif. Karena itu, khalayak hanya menerima apapun yang disajikan kepada mereka dan opini publik menjadi mudah dimanipulasi oleh media massa.

Disisi lain pengguna internet di Indonesia tercatat mengalami peningkatan di tahun 2018 lalu. Berdasarkan hasil studi Polling Indonesia yang bekerja sama dengan Asosiasi Penyelenggara Jasa Internet Indonesia ( APJII), jumlah pengguna internet di Indonesia tumbuh 10,12 persen. Menurut Sekjen APJII, Henri Kasyfi, survei ini melibatkan 5.900 sampel dengan margin of error 1,28 persen. Data lapangan ini diambil selama periode Maret hingga 14 April 2019. Dari data yang dilansir Kompas.com dengan judul "APJII: Jumlah Pengguna Internet di Indonesia Tembus 171 Juta Jiwa. Dari data yang dilansir. Sebanyak 95 persen pengguna Internet di Indonesia adalah pengguna media sosial.

Tak heran bila saat ini nilai-nilai budaya lokal dan norma-norma sosial mulai tereduksi dan terdekonstruksi akibat banyak orang lebih memilih bersosialisasi 
melalui media sosial. Media sosial tidak hanya digunakan untuk berbagi momenmomen menyenangkan dan penting bagi penggunanya, tapi media sosial juga menjadi media informasi bagi banyak kalangan. Namun, di tengah pertumbuhan media sosial yang semakin pesat saat ini, justru menjadi akar masalah dan bumerang dari persoalan-persoalan yang terjadi akhir-akhir ini mengenai persatuan dan kesatuan bangsa.

Media sosial yang menjadi simbol kebebasan masyarakat mengakses komunikasi dan informasi justru menjadi senjata makan tuan bagi persatuan negeri. Kita dengan mudah dapat menjumpai akun-akun yang menebar politik identitas, rasis, kebencian atas nama kelompok, golongan, agama dan perorangan yang beredar luas di media sosial. Inilah embrio radikalisme.

Kasuistik penyebaran radikalisme saat ini justru lebih sering dilakukan melalui media sosial dan diiringi pesatnya dunia digital membuat informasi bertebaran dengan luas. Konten-konten yang ada di media sosial memang memprovokasi, menghegemoni masyarakat baik melalui hoaks, ketidakbenaran dan sebagainya.

Hegemoni media menurut McQuail (1987 : 65) memang mempunyai pengaruh yang sangat luas di masyarakat. Teori hegemoni media menekankan pada ideologi, bentuk ekspresi, cara penerapan serta mekanisme yang dijalankan untuk mempertahankan dan mengembangkan diri melalui kepatuhan pada kelas pekerja sehingga upaya itu berhasil mempengaruhi dan membentuk alam pikiran mereka.

Menurut Antonio Gramsci (1971), hegemoni merujuk pada kepemimpinan moral, filosofis dan politik sebuah kelompok sosial yang tidak diperoleh secara paksa namun dengan persetujuan aktif dari kelompok sosial lainnya melalui kontrol budaya dan ideologi. Yaitu, kelompok sosial dominan yang memberikan dampaknya dan mendapatkan legitimasinya melalui mekanisme sosial seperti pendidikan, agama, keluarga dan media massa.

Sedangkan yang dimaksud dengan hegemoni media adalah dominasi berbagai aspek kehidupan serta pemikiran tertentu dengan menembus budaya dan nilai dominan dalam kehidupan sosial. Hegemoni media berfungsi sebagai pembentuk budaya (baru), nilai dan teknologi masyarakat.

Kebebasan dalam sebuah negara demokrasi, bukanlah kebebasan yang terjadi seperti saat ini. Di mana kita bebas melontarkan hujatan, celaan atau provokasi terhadap pihak lain, bahkan kepada kepala negara dalam hal ini adalah Presiden.

Kebebasan yang terjadi saat ini malah membuat kita tidak mau diatur dan tidak tunduk pada hukum dan perundangundangan. Inilah yang mengakibatkan paham-paham garis keras atau radikal tumbuh subur di Indonesia.

Kebebasan di negara kita yang tidak dibarengi dengan pengetahuan menjadi lahan subur bagi persemaian bibit paham radikal yang subur. Bahkan yang lebih ironis lagi, paham radikalisme justru menyasar kepada generasi-generasi muda. Hal ini bisa dimungkinkan, mengingat pengguna media sosial di Indonesia mayoritas adalah generasi millennial. Dengan gaya hidup hedonisnya, mereka beramai-ramai menggunakan media sosial dengan berbagai macam platformnya.

Didukung jaringan internet dan kecanggihan gadget, smartphone yang semakin kompetitif di pasaran elektronik dunia, sekali lagi, generasi mellenial hanya bertindak sebagai konsumen dan pengguna pasif dengan sedikit pengetahuan teori politik wacana kritis.

Berselancar jauh di dunia maya tanpa dibarengi konstruk pengetahuan politik media dan analisis wacana kritis 
menyebabkan generasi muda sangat rentan terpapar ide, gagasan, pemikiran dan paham radikal yang sudah sangat massif bergerak di dunia ghaib media sosial. Youtube, adalah salah satu fitur favorit generasi muda Indonesia saat ini. Di dalamnya mereka dimanjakan dengan berbagai informasi, suguhan hiburan dan lain sebagainya. Penyebaran paham ajaran radikal salah satunya juga melalui fitur ini.

Hal yang sangat ironis sekaligus mencemaskan bagi masa depan generasigenerasi muda Indonesia ke depan jika tidak ada upaya pemerintah bersama segenap elemen negeri segera merumuskan program kontra ideologi radikal.

\section{Radikalisme}

Radikalisme merupakan paham atau aliran yang mengingikan perubahan atau pembaharuan sosial dan politik dengan cara kekerasan atau drastis. Esensi radikalisme adalah konsep sikap jiwa dalam mengusung perubahan.

Sementara itu

Radikalisme menurut Wikipedia adalah suatu paham yang dibuat-buat oleh sekelompok orang yang menginginkan perubahan atau pembaharuan sosial dan politik secara drastis dengan menggunakan cara-cara kekerasan.

Kata radikalisme ditinjau dari segi terminologis berasal dari kata dasar radix yang artinya akar (pohon). Bahkan anakanak sekolah menengah lanjutan pun sudah mengetahuinya dalam pelajaran biologi. Makna kata tersebut, dapat diperluas kembali, berarti pegangan yang kuat, keyakinan, pencipta perdamaian dan ketenteraman, dan makna-makna lainnya. Kata ini dapatdikembangkan menjadi kata radikal, yang berarti lebih adjektif. Hingga dapat dipahami secara kilat, bahwa orang yang berpikir radikal pasti memiliki pemahaman secara lebih detail dan mendalam, layaknya akar tadi, serta keteguhan dalam mempertahankan kepercayaannya. Memang terkesan tidak umum, hal inilah yang menimbulkan kesan menyimpang di masyarakat. Setelah itu, penambahan sufiks -isme sendirri memberikan makna tentang pandangan hidup (paradigma), sebuah faham, dan keyakinan atau ajaran. Penggunaannya juga sering disambungkan dengan suatu aliran atau kepercayaan tertentu.

Apabila dilihat dari sudut pandang keagamaan dapat diartikan sebagai paham keagamaan yang mengacu pada fondasi agama yang sangat mendasar dengan fanatisme keagamaan yang sangat tinggi, sehingga tidak jarang penganut dari paham/aliran tersebut menggunakan kekerasan kepada orang yang berbeda paham/aliran untuk mengaktualisasikan paham keagamaan yang dianut dan dipercayainya untuk diterima secara paksa.

Adapun yang dimaksud dengan radikalisme adalah gerakan yang berpandangan kolot dan sering menggunakan kekerasan dalam mengajarkan keyakinan mereka. Sementara Islam merupakan agama kedamaian. Islam tidak pernah membenarkan praktek penggunaan kekerasan dalam menyebarkan agama, paham keagamaan serta paham politik.

Dawinsha mengemukakan defenisi radikalisme menyamakannya dengan teroris. Tapi ia sendiri memakai radikalisme dengan membedakan antara keduanya. Radikalisme adalah kebijakan dan terorisme bagian dari kebijakan radikal tersebut. defenisi Dawinsha lebih nyata bahwa radiklisme itu mengandung sikap jiwa yang membawa kepada tindakan yang bertujuan melemahkan dan mengubah tatanan kemapanan dan menggantinya dengan gagasan baru. 
Makna yang terakhir ini, radikalisme adalah sebagai pemahaman negatif dan bahkan bisa menjadi berbahaya sebagai ekstrim kiri atau kanan.

Dapat merujuk pada ekstremisme, dalam politik berarti tergolong kepada kelompok- kelompok kiri radikal, Ekstrem kiri atau Ekstrem kanan. Radikalisasi transformasi dari sikap pasif atau aktivisme kepada sikap yang lebih radikal, revolusioner, ekstremis, atau militan. Sementara istilah "Radikal" biasanya dihubungkan dengan gerakangerakan ekstrem kiri, "Radikalisasi" tidak membuat perbedaan seperti itu.

Ketua umum Dewan Masjid Indonesia, Dr. dr. KH. Tarmidzi Taher memberikan komentarnya tentang radikalisme bemakna positif, yang memiliki makna tajdid (pembaharuan) dan islah (peerbaikan), suatu spirit perubahan menuju kebaikan. Hingga dalam kehidupan berbangsa dan bernegara para pemikir radikal sebagai seorang pendukung reformasi jangka panjang.

Dari berbagai definisi maka dapat dikatakan makna radikalissme, yaitu pandangan/cara berfikir seseorang yang menginginkan peningkatan mutu, perbaikan, dan perdamaian lingkungan multidimensional, hingga semua lapisan masyarakatnya dapat hidup rukun dan tenteram.

Perkembangannya pemahaman terhadap radikalisme itu sendiri mengalami pemelencengan makna, karena minimnya sudut pandang yang digunakan, masyarakat umum hanya menyoroti apa yang kelompok-kelompok radikal lakukan (dalam hal ini praktek kekerasan), dan tidak pernah berusaha mencari apa yang sebenarnya mereka cari (perbaikan). Hal serupapun dilakukan oleh pihak pemerintah, hingga praktis pendiskriminasian terhadap paham yang satu ini tak dapat dielakkan.
Berkaitan dengan Radikalisme, terminology estremisme dalam politik berarti tergolong kepada kelompokkelompok Kiri radikal, Ekstrem kiri atau Ekstrem kanan. Ekstremisme juga adalah istilah yang digunakan untuk menggambarkan sebuah doktrin atau sikap baik politik maupun agama dalam menyerukan aksi dengan segala cara untuk mencapai tujuannya. Ekstremisme adalah berlebih-lebihan dalam beragama, tepatnya menerapkan agama secara kaku dan keras hingga melewati batas kewajaran.

Ekstremisme bukan monopoli satu agama semata. Dalam sejarah Islam berderet nama gerakan ekstrem pernah timbul dan tenggelam. Dikatakan pakar sejarah Islam dari Nottigham University, Inggris, Prof. Hugh Goddard, $\mathrm{Ph} \mathrm{D}$, tidak hanya agama Islam dan Kristen yang mengikuti sikap liberal dan ekstrim, juga pengikut agama lainnya. Di Irlandia ada konflik antara umat Katolik dan Kristen, di India ada ekstrimis Hindu, dan di Indonesia ada ekstrimis muslim.

\section{Pengertian Terorisme}

Secara etimologi terorisme berasal dari kata "to Terror" dalam bahasa inggris. Sementara dalam bahasa latin disebut Terrere yang berarti "gemetar" atau menggetarkan. Dalam Kamus Besar Bahasa Indonesia terror merupakan suatu usaha untuk menciptakan ketakutan, kengerian, dan kekejaman oleh seseorang atau golongan tertentu (Depdikbud, 2013).

Teorisme dalam pengertian perang memiliki definisi sebagai seranganserangan terkoordinasi yang bertujuan membangkitkan perasaan terror (takut), sekaligus menimbulkan korban massif bagi warga sipil dengan melakukan pengeboman atau bom bunuh diri. 
Undang-Undang Nomor 15 tahun 2003 tentang Pemberantasan Tindak Pidana Terorisme, Bab I Ketentuan Umum, Pasal 1 ayat 1 , menyebutkan bahwa Tindak Pidana Terorisme adalah segala perbuatan yang memenuhi unsur-unsur tindak pidana sesuai dengan ketentuan dalam Undang-Undang.

Mengenai perbuatan apa saja yang dikategorikan ke dalam Tindak Pidana Terorisme, diatur dalam ketentuan (Tindak Pidana Terorisme), Pasal 6, 7, bahwa setiap orang dipidana karena melakukan Tindak Pidana Terorisme, jika:

1. Dengan sengaja menggunakan kekerasan atau ancaman kekerasan menimbulkan suasana teror atau rasa takut terhadap orang secara meluas atau menimbulkan korban yang bersifat massal, dengan cara merampas kemerdekaan atau menghilangkan nyawa dan harta benda orang lain atau mengakibatkan kerusakan atau kehancuran terhadap obyekobyek vital yang strategis atau lingkungan hidup atau fasilitas publik atau fasilitas internasional (Pasal 6).

2. Dengan sengaja menggunakan kekerasan atau ancaman kekerasan bermaksud untuk menimbulkan suasana terror atau rasa takut terhadap

orang secara meluas atau

menimbulkan korban yang

bersifat massal, dengan cara

merampas kemerdekaan atau

menghilangkan nyawa dan harta

benda orang lain atau

mengakibatkan kerusakan atau

kehancuran terhadap obyek-

obyek vital yang strategis atau

lingkungan hidup atau fasilitas

publik atau fasilitas internasional

(Pasal 7).

Dan seseorang juga dianggap melakukan Tindak Pidana Terorisme, berdasarkan ketentuan pasal 8, 9, 10, 11 dan 12 Undang-Undang Nomor 15 tahun 2003 tentang Pemberantasan Tindak Pidana Terorisme. Dari banyak definisi yang dikemukakan oleh banyak pihak, yang menjadi ciri dari suatu Tindak Pidana Terorisme adalah:

1) Adanya rencana untuk melaksanakan tindakan tersebut.

2) Dilakukan oleh suatu kelompok tertentu.

3) Menggunakan kekerasan.

4) Mengambil korban dari masyarakat sipil, dengan maksud mengintimidasi pemerintah.

5) Dilakukan untuk mencapai pemenuhan atas tujuan tertentu dari pelaku, yang dapat berupa motif sosial, politik ataupun agama.

\section{METODOLOGI PENELITIAN}


Penelitian ini bersifat kwantitatif dan kualitatif deskriptif dengan menggunakan teknik penggumpulan data berupa observasi, dokumentasi serta Penelusuran data online terkiat deskripsi radikalisme di Minahasa.

Metode deskriptif analisis merupakan metode yang bertujuan mendeskripsikan atau memberi gambaran terhadap suatu objek penelitian yang diteliti melalui sampel atau data yang terkumpul dan membuat kesimpulan yang berlaku secara umum.

Peneliti menggunakan teknik ini karena yang digunakan adalah metode deskiptif kualitatif, dimana memerlukan data-data untuk menggambarkan suatu fenomena yang apa adanya (alamiah). Sehingga benar salahnya, sudah sesuai dengan peristiwa yang sebenarnya. Kemudian data tersebut diolah dan dianalisis dengan pola pikir induktif yang berarti pola pikir yang berpijak pada fakta-fakta yang bersifat khusus kemudian diteliti, dianalisis dan disimpulkan sehingga pemecahan persoalan atau solusi tersebut dapat berlaku secara umum. Peneliti mengkaji dan menganalisis secara mendalam beberapa kejadian kekerasan yang terjadi di dunia utamanya yang dituduhkan terhadap ummat Islam.

Dalam penelitian ini, peneliti menggunakan observasi tidak berstruktur, yaitu observasi yang dilakukan tanpa menggunakan guide observasi. Dengan demikian, pada observasi ini peneliti secara pribadi mengembangkan daya pengamatannya dalam mengamati suatu objek.

Penulis juga melakukan dokumentasi yaitu teknik pengumpulan data yang tidak langsung ditujukan pada subjek penelitian, namun melalui dokumen, yaitu menghimpun data fisik terkait dengan permasalahan yang diteliti.

\section{Media}

Dalam pembahasan "Media diantara Radikalisme Dan Terorisme" dengan tujuan untuk mengetahui seberapa besar pengaruhnya terhadap Islam ( study kasus Minahasa Utara). Penulis melakukan analisis isi (content analysis) adalah penelitian yang bersifat pembahasan mendalam terhadap isi suatu informasi tertulis atau tercetak dalam media massa secara kualitatif. Pelopor analisis isi adalah Harold D. Lasswell, yang memelopori teknik symbol coding, yaitu mencatat lambang atau pesan secara sistematis, kemudian diberi interpretasi.

Dari hasil penelitian terhadap beberapa media nasional paska kejadian pengerusakan Mushola di Minahasa Utara minggu ke-5 Januari dan Minggu Ke-1 Februari 2020, diskripsi soal radikalisme, terorisme, ektrimis dan intoleran nyaris tidak muncul dalam kontruksi pemberitaan. Media terlihat dengan sengaja menghilangkan elemen-elemen dari teknis jurnalistik, dengan bagaimana peristiwa dimaknai dan ditampilkan. Inilah sesungguhnya sebuah realitas politik. Media membangun, menyuguhkan, mempertahankan, dan mereproduksi, suatu peristiwa kepada pembacanya.

Melihat konteks diatas dapat diketahui siapa mengendalikan siapa, siapa lawan siapa, mana kawan mana lawan, mana patron dan mana klien, siapa diuntungkan dan siapa dirugikan, siapa menindas dan siapa tertindas. Sedikitnya ada dua esensi utama dari framing diatas: Pertama, bagaimana peristiwa dimaknai. Ini berhubungan dengan bagian mana yang diliput dan mana yang tidak diliput. Kedua, bagaimana fakta ditulis. Aspek ini berhubungan dengan pemakaian kata, kalimat, dan gambar untuk mendukung gagasan.

Sementara media online mainstream, penulis mencermati sedikitnya 20 berita pada minggu terakhir janunuari hingga awal februari 2020 hanya sebagian kecil media yang menggunakan terminologi; radiakalisme, terorisme, ektrimis dan intoleran.. Disisni penulis memahami bahwa

\section{PEMBAHASAN}

ISSN: 2355-0287, e-ISSN: 2549-3299 
: Media berusaha menonjolkan aspek pengerusakan mushola dan mengaburkan aspek radikalisme dengan fokus pemberitaan secara sadar diarahkan pada aspek tertentu. Akibatnya aspek radiakalisme, terorisme, ektrimis dan intoleran tidak mendapat perhatian dalam konstruksi berita.

Berbeda dengan pemberitaan dengan judul "Siswi Tak Berjilbab Diteror, SMAN 1 Gemolong Akhirnya Ikrar Pancasila" yang dimuat detik.com (20/01/20) terdapat kata "radikalisme dan intoleran". Masih di detik.com (21/01/20) berita berjudul "Ini Alasan Kemenag Bandung Atas Teks Khotbah Jumat" terdapat kata radikal.

Dalam hal ini terlihat jelas sebagian media mencoba menampilkan sisi tertentu dengan melupakan sisi yang lain. Artinya seringnya obyek pemberitaan yang dilatari oleh kelompok Islam selalu diberi lebel radikal dan intoleran. Dengan menampilkan aspek tertentu dalam suatu berita menyebabkan aspek lain yang penting dalam memahami realitas tidak mendapatkan liputan yang memadai dalam berita.

Begitu juga dari pesan pemerintah dalam menyikapi pemberitaan pengerusakan Mushala di Minahasa Utara lebih cenderung mencari aman, pernyataan cenderung normative, seperti yang disampaikan kapolda Sulut dan bupati Minahasa Utara. Disisi lain beberapa pernyataan dari kelompok Islam dari garis "keras" cenderung ditiadakan, dalam data penulis hanya menemukan satu video di saluran youtube pada 31/01 (https://www.youtube.com/watch?v=yNxTpH qSOBA) mengutuk dengan keras kejadian di Minahasa, bahkan diantara mereka siap Jihad.

Penulis mendapat gambaran dalam proses pemberitaan biasanya menampilkan aktor tertentu dan menyembunyikan actor lain. Dengan kata lain berita seringkali juga memfokuskan pemberitaan pada aktor tertentu. Ini tentu saja tidak salah. Namun efek yang segera terlihat adalah memfokuskan pada satu pihak atau aktor tertentu menyebabkan aktor lain yang mungkin relevan dan penting dalam pemberitaan menjadi tersembunyi.
Terkait faktor komunikasi di media sosial yang memiliki karakter tanpa batas membuat penyebaran paham radikal semakin sulit dihalau. Tanpa disadari media sosial itu bersifat borderless dan luas, partisipatif dengan peserta beragam, bersifat private dalam penggunaan, komunikasi bebas dan cepat dan pesan mudah dibuat.

Karakter media sosial itu berseiring dengan meningkatnya penggunaan media sosial, semakin mempercepat penyebaran paham radikal di media sosial. Percepatan paham radikalisme menyebar juga disebabkan oleh akselerasi pengguna internet yang meningkat. Dominasi situs-situs hoaks dan radikalisme juga masih tinggi.

Peran media sosial meningkatkan intensitas sentimen tirani mayoritanisme Minahasa Utara adalah sebuah keniscayaan dan menjadi preseden buruk bagi relasi keberagamaan sekaligus praktik demokrasi di Indonesia. Hal ini disebabkan sentimen tirani mayoritanisme umumnya mengejawantah ke dalam praktik social exclude, yakni praktik pengucilan sosial yang dilakukan oleh kelompok mayoritas terhadap minoritas

\section{Terorisme}

Dalam pengerusakan Mushola di Minahasa Utara, dugaan sementara penyebab perusakan karena warga menolak perizinan pembangunan rumah ibadah. Satu orang terduga provokator pun telah diamankan polisi, namun tidak menutup kemungkinan ada pelaku lainnya yang terlibat, sehingga akan diperiksa kepolisian

Sama halnya dengan beberapa kasus pengeboman, terorisme dan lain sebagainya merupakan akibat daripada paham radikal yang telah meningkat menjadi sebuah tindakan yang sangat merugikan banyak pihak, bahkan banyak orang yang tidak bersalah terkena imbasnya. Radikalisme apabila dibiarkan akan membawa dampak negatif yang lebih besar terutama bagi kehidupan beragama. sehigga untuk mengatasi hal tersebut perlunya diadakan beberapa penanganan dari semua aparatur negara, yaitu, rakyat, tokoh agama, serta penegak hukum juga diadakan 
deradikalisasi. sehingga dalam pemahaman agama diajarkan keterampilan pemecahan masalah tanpa kekerasan, mampu berfikir kritis, toleransi, dan pemahaman agama secara integratif tidak menimbulkan bias.

Menurut Muzadi adalah (seseorang yang) tumbuh menjadi reaktif ketika terjadi ketidakadilan di masyarakat. Biasanya radikalisasi tumbuh berkaitan dengan ketikadilan ekonomi, politik, lemahnya penegakan hukum dan seterusnya. Jadi, jangan dibayangkan ketika teroris sudah ditangkap, lalu radikalisme hilang. Sepanjang keadilan dan kemakmuran belum terwujud, radikalisasi akan selalu muncul di masyarakat. Keadilan itu menyangkut banyak aspek, baik aspek hukum, politik, pendidikan, sosial, hak asasi, maupun budaya. Hukum itu berbeda dengan keadilan.

Hukum adalah aspek tertentu, sedangkan keadilan adalah akhlak dari hukum itu Potensi berpikir, bersikap dan bertindak radikal, berideologi radikal (radikalisme) dan tumbuh reaktif menjadi radikal (radikalisasi) adalah modal awal seseorang menjadi pelaku teror (teroris) atau orang yang berpaham terror (terorisme). Tidak ada teror tanpa radikalisme. Sebaliknya penganut radikalisme belum tentu menyukai jalan kekerasan (teror). Sekalipun demikian, terdapat kesamaan bahasa yang digunakan oleh radikalisme maupun terorisme, yaitu bahasa militan atau bahasa perjuangan (language of militance).

Terkait dengan kelompok mayoritas Kristen di Minahasa Utara yang melakukan tindakan anarkis dengan kekuatan massa dan posisi tawarnya akan melakukan tindakan pengucilan (exclution) terhadap kaum minoritas yang memiliki sistem kepercayaan atau keyakinan yang tidak sejalan dengan pandangan arus utama. Dengan mengatasnamakan dalil dan teks-teks keagamaan, kelompok mayoritas tidak segan melakukan tindakan represif terhadap kelompok agama minoritas adalah perbuatan terorisme.

Dengan tujuan akhir membuat kaum minoritas merasa tertekan, tersingkir lantas menerima dominasi kaum mayoritas. Dampak dari praktik pengucilan ini sangat fatal bagi kerukunan antar umat beragama. Pengucilan akan melahirkan relasi sosial-keagamaan yang timpang. Kelompok mayoritas memiliki daya tawar dan daya tekan yang kuat untuk memaksakan aturan main di ruang publik. Sebaliknya, kelompok minoritas akan kehilangan kanal-kanal ekspresi karena tersumbat oleh spiral aroganisme.

Peristiwa Minahasa Utara merupakan tirani mayoritanisme adalah patologi sosialkeberagamaan yang membahayakan. Tirani mayoritanisme pada dasarnya mengingkari fitrah dan esensi agama yang menjunjung tinggi kebebasan dan hak asasi manusia. Apalagi secara historis, masing-masing agama, terutama yang ada di rumpun Abrahamic Religion (Islam, Kristen, Yahudi) memiliki keterkaitan ajaran satu sama lain yang mustahil dipisahkan. Agama-agama dalam rumpun agama Ibrahim tidak pernah berdiri sendiri. Ketiganya bertautan baik secara konsep teologi maupun ritusnya

Tirani mayoritanisme adalah pola pikir atau perilaku yang menunjukkankecenderungan arogan, despotik dan superior serta merasa diri paling berkuasa. Ekspresi sosial itu muncul dilatari oleh kesadaran komunal bahwa kelompok yang berjumlah banyak harus selalu lebih dominan dan diistimewakan ketimbang kelompok dengan jumlah lebih sedikit. Tirani mayoritas adalah patologi sosial yang acapkali menjadi batu sandungan bagi terciptanya tata kehidupan sosial-politik yang harmonis dan egaliter.

\section{PENUTUP}

Dari hasil penelitian terhadap beberapa media mainstream nasional paska kejadian pengerusakan Mushola di Minahasa Utara minggu ke-5 Januari dan Minggu ke-1 Februari 2020, diskripsi soal radiakalisme, terorisme, ektrimis dan intoleran nyaris tidak muncul dalam kontruksi pemberitaan. Media terlihat dengan sengaja menghilangkan elemen-elemen dari teknis jurnalistik, dengan bagaimana peristiwa dimaknai dan ditampilkan. Inilah sesungguhnya sebuah 
realitas politik. Media membangun, menyuguhkan, mempertahankan, dan mereproduksi, suatu peristiwa kepada pembacanya dengan motif masing-masing .

$$
\text { Media memiliki kekuatan }
$$

memaksa, bahkan secara langsung dapat mempengaruhi pikiran orang dan mengubah pandangan mereka tentang dunia sosial. Ratarata orang sangat rapuh atau tidak berdaya menghadapi media karena dalam masyarakat massa mereka diisolasi dari institusi sosial tradisional yang sebelumnya melindungi mereka dari manipulasi media. Peristiwa kekacauan sosial di Minahasa Utara yang diinisiasi oleh media kemungkinan akan di atasi dengan pembentukan tatanan sosial mayoritas yang totaliter.

Sepanjang keadilan dan kemakmuran belum terwujud, radikalisasi akan selalu muncul di masyarakat. Keadilan itu menyangkut banyak aspek, baik aspek hukum, politik, pendidikan, sosial, hak asasi, maupun budaya. Hukum itu berbeda dengan keadilan.

Hukum adalah aspek tertentu, sedangkan keadilan adalah akhlak dari hukum itu Potensi berpikir, bersikap dan bertindak radikal, berideologi radikal (radikalisme) dan tumbuh reaktif menjadi radikal (radikalisasi) adalah modal awal seseorang menjadi pelaku teror (teroris) atau orang yang berpaham terror (terorisme). Tidak ada teror tanpa radikalisme. Sebaliknya penganut radikalisme belum tentu menyukai jalan kekerasan (teror).

$$
\text { Indonesia yang multikultur }
$$
sekaligus multireligi, relasi sosial-keagamaan idealnya bertumpu pada corak keberagamaan intersubjektif, yakni relasi keberagamaan yang bertumpu pada rasa saling memahami, simpati, empati, dan mengedepankan sikap inklusif-dialogis dalam menyikapi perbedaan. Model keberagaman intersubjektif mensyaratkan kerangka pikir yang moderat (wasathiyah) dalam menyikapi keanekaragaman agama, aliran, mazhab, kepercayaan dan ekspresi keagamaan di ruang publik.

Setiap persoalan yang berkaitan dengan perbedaan diselesaikan dengan caracara dialogis. Di sinilah pentingnya peran media dan kelompok agama menyisakan ruang bagi terciptanya diskursus keagamaan yang sehat dan dilandasi spirit integrasi sosial.

Konflik antar-umat beragama di banyak negara menunjukkan bahwa konflik antar-umat beragama pada umumnya tidak dilatari oleh persoalan perbedaan keyakinan teologis, melainkan faktor sosial, seperti kesenjangan ekonomi dan ketidakadilan politik. Namun tidak dapat dipungkiri peran media juga meyulut konflik baru dalam zona yang berbeda. Padahal perbedaan keyakinan teologis, kerap hanya dijadikan sebagai alat untuk menjustifikasi tindakan intoleransi dan kekerasan terhadap kelompok agama lain. Media ibarat pedang bermata dua salah satunya dapat memberikan sumbangsih spirit keberagamaan intersubjektif, terhadap relasi sosial-keagamaan di Indonesia bisa berjalan tanpa diwarnai kecurigaan, kebencian dan intoleransi.

Sudah waktunya media dapat mengintensifkan dialog antaragama yang bertujuan untuk membongkar sikap kecurigaan dan kebencian yang menjadi muasal bagi munculnya konflik agama. Dialog agama tidak dikerangkakan untuk memperdebatkan ajaran agama dan mencari mana yang paling benar, namun lebih bertujuan menciptakan perjumpaan teologis, sosiologis sekaligus psikologis antar-umatberagama.

Industri media harus dapat mengembangkan corak keberagamaan kosmopolitan, yakni pandangan yang meyakini bahwa semua manusia meski berasal dari entitas agama, suku, budaya, ras dan etnis yang berbeda sebenarnya memiliki standar nilai moral dan etika yang sama. Pandangan kosmpolitan dalam beragama ini perlu dikembangkan lantaran praktik intoleransi agama kerap terjadi karena munculnya persepsi buruk yang disematkan kelompok agama tertentu terhadap entitas agama lain. Termasuk terminology radikal, intoleran dan teroris yang selama disematkan terhadap Islam harus segera dihilangkan.

Terakhir penulis berharap pemerintah segera mewujudkan keadilan sosial, ekonomi dan politik di tengah 
masyarakat. Unsur keadilan sosial menjadi hal prasyarat penting terciptanya perdamaian dan harmoni antar umat beragama. Tanpa keadilan, bisa dipastikan relasi sosialkeagamaan akan diwarnai dengan kecemburuan sosial. Hal inilah yang menjadi faktor pemicu munculnya tindakan intoleran bahkan kekerasan.

\section{REFRENSI}

Abbas, Anwar. "Sistem Ekonomi Islam: Suatu Pendekatan Filsafat, Nilai-nilai Dasar, dan Instrumental." Al-Iqtishad: Jurnal Ilmu Ekonomi Syariah 4.1 (2012).

Afrialldi, Riz, and Dedi Kurnia Syah Putra. "Analisis Wacana Hegemoni Melalui Film Dokumenter'jakarta Unfair'." eProceedings of Management 5.2 (2018).

Ali ,Muhammad, Teologi PluralisMultikultural, Jakarta: Kompas, 2003.BurhanBungin, Penelitian Kualitatif, Jakarta: Kencana, 201

Anshari, Endang Saifuddin, Wawasan Islam: Pokok-pokok Fikiran tentang Islam dan Ummatnya, Edisi II Jakarta : CVRajawali, 1986

Burhan Bungin, Metodologi Penelitian Sosial: Format-format Kuantitatif dan Kualitatif Surabaya: Airlangga University Press, 2001.

Daradjat, Zakiah, Islam dan Kesehatan Mental, Jakarta: Gunung Agung, 1983

Daley, Patrick, Patrick J. Daley, and Beverly Ann James. Cultural politics and the mass media: Alaska Native voices. Vol. 148. University of Illinois Press, 2004.

Danesi, Marcel. "The forms and functions of slang." Semiotica 2010.182 (2010): 507-517

Falah, Fajrul. "Hegemoni Ideologi dalam Novel Ayat-Ayat Cinta Karya Habiburrahman el Shirazy (Kajian Hegemoni Gramsci)." Nusa: Jurnal Ilmu Bahasa dan Sastra 13.3 (2018): 351-360.

Hadi, Ido Prijana. Penyiaran Interaktif dan Kepentingan Publik. Diss. Petra Christian University, 2014

Hadinata, Restu Pratama. DERADIKALISASI TERHADAP PARA MANTAN ANGGOTA
TERORISME DI INDONESIA. Diss. Fakultas Hukum Unpas.

Hartono RUDI. EFEKTIVITAS UNDANGUNDANG NOMOR 15 TAHUN 2003 TENTANG PEMBERANTASAN TINDAK PIDANA TERORISME DALAM UPAYA PENINGKATAN INVESTASI DI SULAWESI SELATAN (KAJIAN SOSIOLOGI HUKUM). Diss. 2015

John L. Wsposito, Islam Warna Warni, Paramadina: 2004

Kartono, Kartini, Pengantar Metodologi Rasearch, Bandung: Alumni, 1995).

Luthfi, Khabib. Masyarakat Indonesia dan Tanggung Jawab Moralitas. GUEPEDIA, 2018.

Permata, Ahmad Norma Agama dan Terorisme, Muhammadiyah University Press: 2005

Pieris, John. Tragedi Maluku: sebuah krisis peradaban: analisis kritis aspek politik, ekonomi, sosial budaya, dan keamanan. Yayasan Obor Indonesia, 2004.

Qardhawi, Yusuf, Islam Radikal: Analisis terhadap Radikalisme dalam Berislam dan Upaya Pemecahannya, (terj.) Hamin Murtadho, Solo: Era Intermedia, 2014

Rahman, Tezar Aditya. Hegemoni Media Islam Dalam Wacana Separatisme Negara Kesatuan Republik Indonesia Pada Berita Qanun Bendera Dan Lambang Aceh Dalam Surat Kabar Republika. BS thesis. Fakultas Ilmu Dakwah dan Ilmu Komunikasi Universitas Islam Negeri Syarif Hidayatullah Jakarta.

Sari, Benedicta Dian Ariska Candra. "Media Literasi dalam Kontra Propaganda Radikalisme dan Terorisme Melalui Media Internet." Peperangan Asimetrik 3.1 (2017).

Setiawan, Ananto, Riztina Dwi Setyasih, and Leica Jastien Hosana. "ANALISIS FAKTORFAKTOR PENERIMAAN PENGGUNAAN FINANCIAL TECHNOLOGY PADA SISTEM PEMBAYARAN TRANSPORTASI ONLINE: THEORY OF PLANNED BEHAVIOR (TPB)." Monex: Journal Research Accounting Politeknik Tegal 9.1 (2020): 3037. 
Sudiyarti, Sudiyarti. "BAGAIMANA Sukmadinata, Nana Syaodih, Jenis-jenis PEMERINTAH DAERAH PROVINSI Penelitian, Cet III, Bandung: PT. Remaja KALIMANTAN TIMUR PEDULI IKUT MEMBERANTAS FAHAM RADIKAL." LEGALITAS 3.1 (2018): 47-58.

Sugiyono, Metode Penelitian Kualitatif Kuantitatif dan R\&amp;D, Bandung: Alfa Beta, 2008.

Suharto, Toto, Jafar Assagaf, and Suparmin Suparmin. "MEMBENDUNG ARUS PAHAM KEAGAMAAN RADIKAL: Analisis Ideologi atas Materi Kurikulum dalam Buku Muslim Integral: Buku Program Pendampingan Pengembangan Kepribadian Muslim Integral (P3KMI) Fakultas Tarbiyah dan Bahasa Periode 2012/2013." IAIN Surakarta (2014). Rosdakarya, 2007.

Jurnal:

Yunus, A. Faiz. "Radikalisme, Liberalisme dan Terorisme: Pengaruhnya Terhadap Agama Islam." Jurnal Studi AlQur'an 13.1 (2017): 76-94.

\section{Biodata Penulis}

Arvin Hardian

S1 Komunikasi Jurusan, JurnalistikJurnalistik, S2 Manajemen Konsentrasi Komunikasi. Staf pengajar Ilmu Komunikasi di Universitas Bina Sarana Informatika 